\title{
Current Trends in Practice of Residents in the Saudi Board of Endodontics Program
}

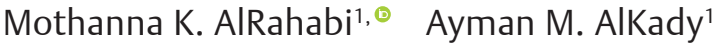 \\ ${ }^{1}$ Department of Restorative Dental Science, College of Dentistry, Taibah \\ University, Al Madinah Al Munawwarah, Kingdom of Saudi Arabia
}

\begin{abstract}
Address for correspondence Mothanna AlRahabi, MSc, PhD, Department of Restorative Dental Science, College of Dentistry, Taibah University, PO Box 2898, Al Madinah Al Munawwarah 43353, Kingdom of Saudi Arabia (e-mail:dr.rahabi@gmail.com; mrahabi@taibahu.edu.sa).
\end{abstract}

\begin{abstract}
Keywords

- Saudi Board of Endodontics

- endodontic therapy

- radiography

- root canal

- surveys

- technology

Objectives The purpose of the current study was to collect information about some techniques and armamentarium currently used by the Saudi Board of Endodontics residents in relation to the technical steps of root canal therapy.

Materials and Methods A web-based survey was sent to the Saudi Board of Endodontics residents, based in the western area of Saudi Arabia. The survey assessed controversial concepts, and collected information regarding new instruments and materials, used in the technical steps of nonsurgical root canal treatment. A one-sample chi-square test, with a $95 \%$ level of significance, was applied to determine whether there were significant differences between respondents' answers.

Results A total of 45 out of 50 residents (90\%) responded to the questionnaire. The majority of Saudi Board residents of Endodontics, who participated in this survey, used the mean of working length (ML) measured by periapical X-Ray and apex locator in the presence of a radiographic lesion (63.3\%), and maintained apical patency in all cases (80.0\%). ProTaper Universal (40\%) and ProTaper Next (41.2\%) were the most common $\mathrm{NiTi}$ rotary systems used for root canal instrumentation. Thirty percent of respondents used adjunct device with irrigation, and $80 \%$ advocated smear layer removal. Zinc oxide-eugenol-based sealers were the most common used sealers (70\%), and most residents (86.6\%) did not advocate sealer extrusion.

Conclusions This study revealed that residents of the Saudi Board of Endodontics program adopt new endodontic technologies. There is, however, a need for more investigations regarding this objective, including responses from all residents in Saudi Arabia.
\end{abstract}

\section{Introduction}

Recent years have witnessed a revolution in trends and technologies within the field of endodontics. ${ }^{1,2}$ Electronic apex locators, smart electronic motors, nickel-titanium rotary and reciprocating files, irrigation devices and activators, ultrasonic endodontic tips, operating microscope, thermoplastic obturation devices, and cone beam-computed tomography, are all advances that have enhanced and improved the practice of root canal therapy, ${ }^{3}$ thereby affecting the daily practice of endodontics. ${ }^{4}$ A questionnaire survey is a common tool to collect information regarding attitudes toward new advances and technologies in the endodontics world. ${ }^{3,5-9}$ The following surveys have been performed with respect to different parts of endodontics practice: irrigation solutions and methods, ${ }^{6,10}$ antibiotic use by endodontists, ${ }^{11}$ cone beam-computed tomography in endodontic practice, ${ }^{12}$ endodontic procedures related to mineral trioxide aggregate usage,,$^{13}$ confidence in performing endodontic treatment,,$^{14}$ cleaning and shaping of root canal systems with nickel-titanium instruments, ${ }^{15}$ magnification, ${ }^{7}$ and knowledge and attitude in the management of dental trauma. ${ }^{16} \mathrm{~A}$ decreasing dentists-to-population ratio, 
and the growing tendency for patient referral from general practitioners to specialty dentists, have both made it necessary to increase the number of specialized dentists. ${ }^{17}$ The Saudi Commission for Health Specialties (SCFHS) established the Saudi Board of Endodontics in 2007. This four-year program has been designed to graduate endodontists with satisfactory knowledge, skills, and clinical experience, along with sufficient background in basic biological science. These objectives are achieved by clinical training, lectures, book reviews, current and classic literature, seminars, quizzes, as well as case presentations. Until now, there have been no studies regarding the trends of Saudi Board of Endodontics' residents during their training and practice of daily endodontic treatment. The purpose of this study was to collect information about certain techniques and armamentarium currently used by them to perform the technical steps of root canal therapy.

\section{Materials and Methods}

This study was approved by the research ethics committee of the College of Dentistry-Taibah University Protocol no. TUCDREC/20171220/Alrahabi in agreement with the guidelines of the Helsinki Declaration revised in 1975. A webbased survey, created using Google forms, was emailed to the residents of Saudi Board of Endodontics in Saudi Arabia. The survey included the aim and the importance of this research and seven multiple choices; - Table 1 shows the included questions. The link was sent to 50 residents. E-mail remainders were sent to those who had not responded within 3 weeks after the first message. The survey was designed to address controversial concepts, and collect information regarding certain instruments and materials, used recently in relation to the technical steps of nonsurgical root canal treatment: modification of working length (WL) in the presence of radiographic lesion; maintenance of apical patency of the root canal during cleaning and shaping; NiTi system used for root canal instrumentation; use of an adjunct devices for root canal irrigation during cleaning and shaping; attitude regarding smear layer removal; type of sealer used for root canal obturation; and attitude regarding sealer extrusion from the apex; - Table 1 shows the questionnaire items. A one-sample chi-square test, at $95 \%$ significance level, was applied to determine whether there were significant differences among residents' answers.

\section{Results}

A total of 45 out of 50 residents (90\%) responded to the questionnaire. The frequency of residents-who depended on the mean of WL, as measured by periapical X-Ray and apex locator in the presence of a radiographic lesion (63.3\%)-was significantly higher than those who measured the WL by apex locator only or by reducing the length by 1 to $2 \mathrm{~mm}$ from radiographic apex. Maintaining apical patency in all cases was significantly higher (80\%) than
Table 1 Questionnaire items

\begin{tabular}{|c|c|c|}
\hline No. & Question & Answers \\
\hline 1 & $\begin{array}{l}\text { Do you advocate } \\
\text { changing work- } \\
\text { ing length based } \\
\text { on the presence } \\
\text { of a radiographic } \\
\text { lesion? }\end{array}$ & $\begin{array}{l}\text { 1. Yes, I advocate reducing WL } \\
1-2 \text { mm from radiographic } \\
\text { apex } \\
\text { 2. We use measurements of apex } \\
\text { locator } \\
\text { 3. We use measurements of } \\
\text { apex locator and paper point } \\
\text { bleeding point } \\
\text { 4. We use the mean of WL } \\
\text { measured by X-Ray and apex } \\
\text { locator }\end{array}$ \\
\hline 2 & $\begin{array}{l}\text { Do you maintain } \\
\text { apical patency? }\end{array}$ & $\begin{array}{l}\text { 1. In all cases } \\
\text { 2. In necrotic cases } \\
\text { 3. In retreatment cases } \\
\text { 4. In necrotic and retreatment } \\
\text { cases }\end{array}$ \\
\hline 3 & $\begin{array}{l}\text { What NiTi system } \\
\text { do you use } \\
\text { for root canal } \\
\text { instrumentation? }\end{array}$ & $\begin{array}{l}\text { 1. Not specific } \\
\text { 2. ProTaper Universal } \\
\text { 3. ProTaper Next } \\
\text { 4. Reciproc } \\
\text { 5. Vortex blue } \\
\text { 6. Others specify }\end{array}$ \\
\hline 4 & $\begin{array}{l}\text { Do you use any } \\
\text { adjunct device } \\
\text { to activate } \\
\text { irrigation? }\end{array}$ & $\begin{array}{l}\text { 1. No activation } \\
\text { 2. Endo activator } \\
\text { 3. Endo vac } \\
\text { 4. Others specify }\end{array}$ \\
\hline 5 & $\begin{array}{l}\text { Do you advocate } \\
\text { remove smear } \\
\text { layer? }\end{array}$ & $\begin{array}{l}\text { 1. Yes } \\
\text { 2. No } \\
\text { 3. There is no difference }\end{array}$ \\
\hline 6 & $\begin{array}{l}\text { What is the } \\
\text { sealer type do } \\
\text { you use? }\end{array}$ & $\begin{array}{l}\text { 1. Zinc oxide-eugenol sealers } \\
\text { 2. Calcium hydroxide sealers } \\
\text { 3. GIC sealers } \\
\text { 4. Epoxy or methacrylate resins } \\
\text { sealers } \\
\text { 5. Bioceram sealers } \\
\text { 6. Others specify }\end{array}$ \\
\hline 7 & $\begin{array}{l}\text { Do you advocate } \\
\text { sealer extrusion } \\
\text { from the apex? }\end{array}$ & $\begin{array}{l}\text { 1. I do not advocate sealer } \\
\text { extrusion } \\
\text { 2. I advocate sealer extrusion } \\
\text { 3. I advocate sealer extrusion in } \\
\text { necrotic cases } \\
\text { 4. I advocate sealer extrusion in } \\
\text { retreatment cases } \\
\text { 5. I advocate sealer extrusion in } \\
\text { all cases }\end{array}$ \\
\hline
\end{tabular}

Abbreviation: WL, working length.

those who only maintained it in cases of necrosis. ProTaper Next (43.3\%) and ProTaper Universal (40\%) NiTi rotary systems were significantly used more than other types of NiTi systems. The majority of respondents (70\%) performed irrigation of root canal system without any type activation. Most of the respondents (80\%) were routinely removing the smear layer during endodontic treatment. Zinc oxideeugenol-based sealers were the most commonly used sealers (66.7\%) and significantly higher than other types of sealers. The majority of respondents (86.6\%) were against the sealer extrusion from apical foramen. The responses of participants were summarized in -Table 2 using frequencies and percentages for different items on the 
Table 2 Frequencies and percentages for residents' answers to questionnaire items

\begin{tabular}{|c|c|c|c|c|}
\hline No. & Studied Item & Answers & $\begin{array}{l}\text { Number of } \\
\text { respondents }\end{array}$ & Percentage \\
\hline \multirow{3}{*}{1} & \multirow{3}{*}{$\begin{array}{l}\text { Determination of working length in } \\
\text { the presence of a radiographic lesion }\end{array}$} & $\begin{array}{l}\text { Reduce WL 1-2 mm from radio- } \\
\text { graphic apex }\end{array}$ & 1 & $3.3 \%$ \\
\hline & & $\begin{array}{l}\text { Using the measurements of apex } \\
\text { locator }\end{array}$ & 15 & $33.3 \%$ \\
\hline & & $\begin{array}{l}\text { Use the mean of WL, as mea- } \\
\text { sured by X-Ray and apex locator }\end{array}$ & 29 & $63.3 \%$ \\
\hline \multirow[b]{2}{*}{2} & \multirow[b]{2}{*}{ Maintain apical patency } & In all cases & 36 & $80.0 \%$ \\
\hline & & $\begin{array}{l}\text { In necrotic and retreatment } \\
\text { cases }\end{array}$ & 9 & $20.0 \%$ \\
\hline \multirow{5}{*}{3} & \multirow{5}{*}{$\begin{array}{l}\text { NiTi system used for root canal } \\
\text { instrumentation }\end{array}$} & No specific preference & 1 & $3.3 \%$ \\
\hline & & ProTaper Universal & 18 & $40.0 \%$ \\
\hline & & ProTaper Next & 19 & $41.2 \%$ \\
\hline & & Reciproc & 6 & $12.2 \%$ \\
\hline & & Vortex blue & 1 & $3.3 \%$ \\
\hline \multirow{3}{*}{4} & \multirow{3}{*}{ Use of adjunct device for irrigation } & No activation & 31 & $70.0 \%$ \\
\hline & & Endo activator & 12 & $26.7 \%$ \\
\hline & & Endo vac & 2 & $3.3 \%$ \\
\hline \multirow{3}{*}{5} & \multirow{3}{*}{ Removal of smear layer } & Advocate smear layer removal & 36 & $80.0 \%$ \\
\hline & & $\begin{array}{l}\text { Do not advocate smear layer } \\
\text { removal }\end{array}$ & 1 & $3.3 \%$ \\
\hline & & No difference in outcome & 8 & $16.7 \%$ \\
\hline \multirow{4}{*}{6} & \multirow{4}{*}{ Sealer type } & Zinc oxide-eugenol sealers & 30 & $66.7 \%$ \\
\hline & & Calcium hydroxide sealers & 5 & $11.1 \%$ \\
\hline & & $\begin{array}{l}\text { Epoxy or methacrylate resin } \\
\text { sealers }\end{array}$ & 5 & $11.1 \%$ \\
\hline & & Bioceramic sealers & 5 & $11.1 \%$ \\
\hline \multirow{3}{*}{7} & \multirow{3}{*}{$\begin{array}{l}\text { Advocate sealer extrusion from the } \\
\text { apex }\end{array}$} & Do not advocate sealer extrusion & 39 & $86.6 \%$ \\
\hline & & $\begin{array}{l}\text { Advocate sealer extrusion in } \\
\text { necrotic cases }\end{array}$ & 1 & $3.3 \%$ \\
\hline & & $\begin{array}{l}\text { Advocate sealer extrusion in all } \\
\text { cases }\end{array}$ & 5 & $11.1 \%$ \\
\hline
\end{tabular}

Abbreviation: WL, working length.

questionnaire. The attitudes of residents toward investigated techniques and armamentarium during their practice are shown in - Figs. 1 and 2.

\section{Discussion}

The present study was designed to collect information regarding the trends and attitudes of the residents of Saudi Board of Endodontics toward some controversial concepts, and new instruments and materials, used during nonsurgical root canal treatment. The majority of participants used the mean of WL, as measured by both periapical radiograph and apex locator; only $33.3 \%$ depended on the measurement of apex locator. The recommended method to measure WL involves electronic devices, followed by radiographic confirmation. ${ }^{18}$ Modern apex locators has proven to be a reliable device for WL measurement ${ }^{19}$. Maintaining apical patency in all cases was significantly higher than those who only maintained it in cases of necrosis According to the American Association of Endodontists, apical patency is a technique where the apical portion of the canal is maintained free of debris by recapitulation with a small file through the apical foramen ${ }^{20}$. Since 1997, 50\% of dental schools in the United States have taught the patency concept ${ }^{21}$. One study revealed that maintaining apical patency did not introduce microorganisms into the periapical tissues ${ }^{22}$ and improved irrigation efficiency in the apical third. ${ }^{23}$ Further, maintenance of apical patency did not increase postoperative pain of root canal treatment in necrotic cases, where all these cases in this study had preoperative radiolucency. ${ }^{24} \mathrm{NiTi}$ rotary instrumentation is considered a basic component of the recent endodontic practice. Several rotary nickel-titanium (Ni-Ti) file systems have been introduced for the preparation of root canals. Ni-Ti instruments provide many advantages compared with conventional files. 


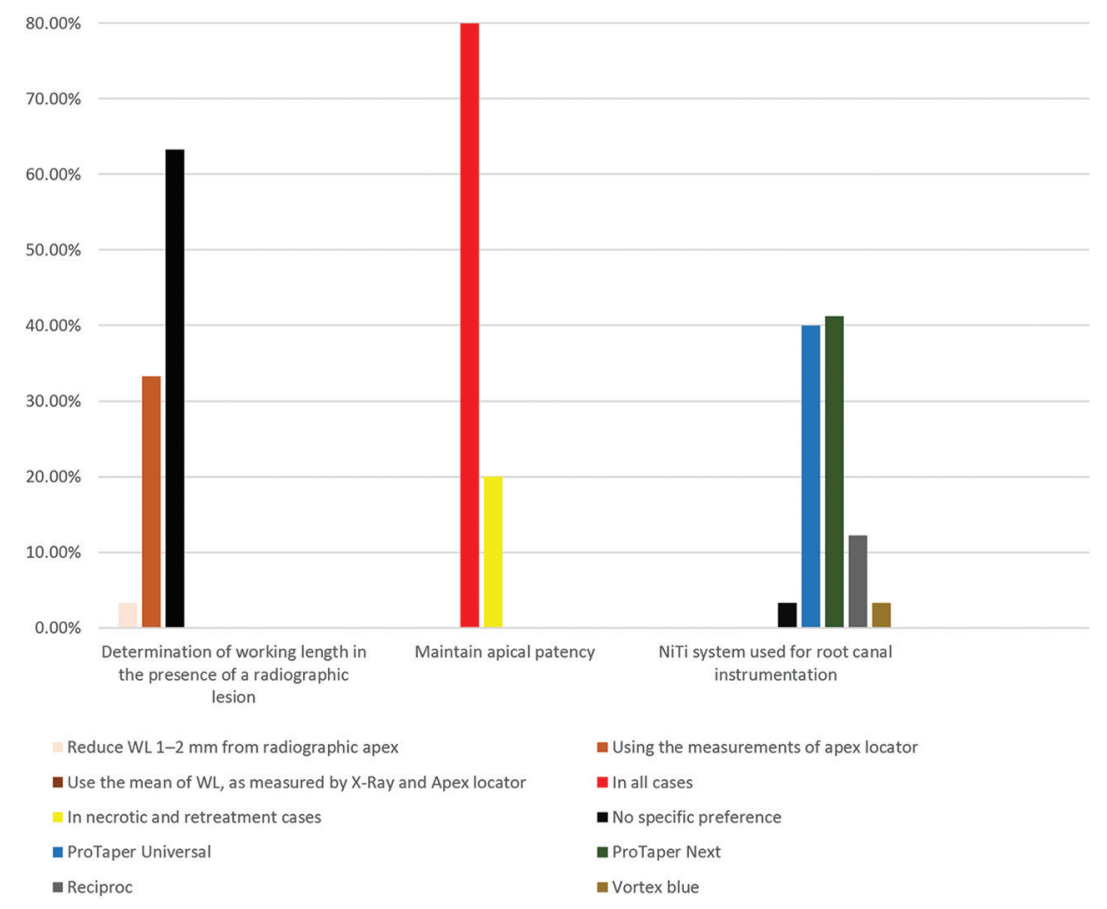

Fig. 1 Attitudes of Saudi Board of Endodontics residents during their training part 1.

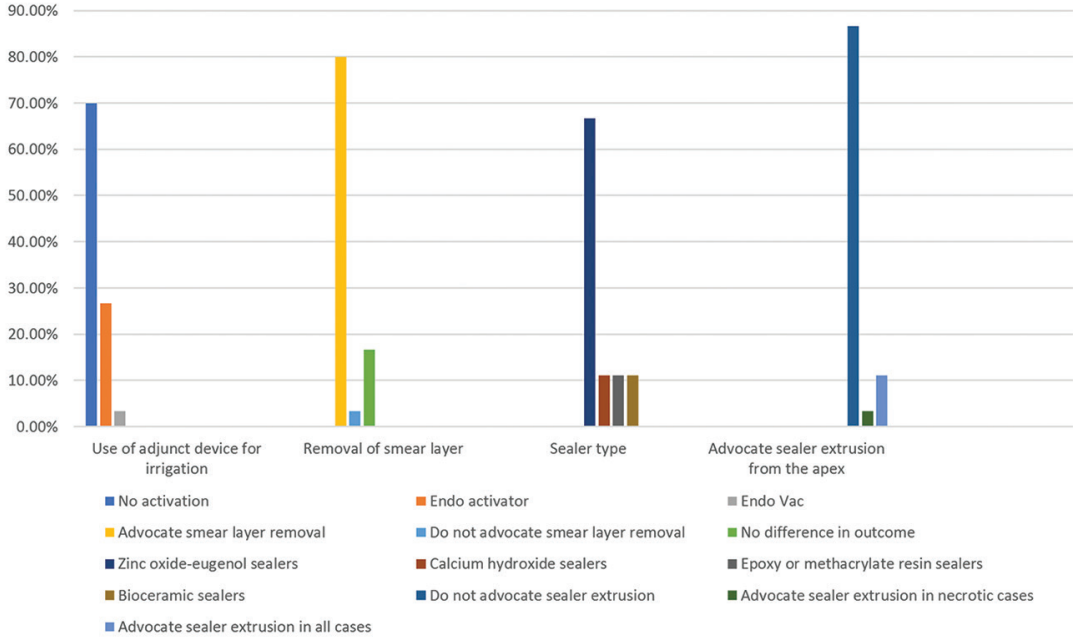

Fig. 2 Attitudes of Saudi Board of Endodontics residents during their training part 2.

Increased flexibility and shortened working time are the major advantages of Ni-Ti files. ${ }^{25}$ In this study, ProTaper Next and ProTaper Universal NiTi rotary systems were significantly used more than other types of NiTi systems. However, the selection of NiTi system maybe be affected by their availability. ProTaper systems are produced by Dentsply-Tulsa Dental [Oklahoma, USA], which has an active marketing strategy that might explain the widespread preference for this system. ${ }^{26}$ Both ProTaper Universal and ProTaper Next can preserve the original curvature of the canal. ${ }^{27}$ Reciproc, which is a single-file system was used by $12.2 \%$ of participants in this survey, has been specifically designed for use in reciprocating motion, with high resistance to cyclic fatigue, ${ }^{28}$ Moreover, the use of only one NiTi instrument is more cost-effective. ${ }^{29}$ However, the selection of NiTi system maybe be affected by the availability or desire to experiment with a new NiTi system. Vortex Blue NiTi system was used with a small percentage of participants, and it can also be attributed to availability or marketing. Vortex Blue has a high-cyclic fatigue resistance. ${ }^{30}$ A recent survey revealed that $82 \%$ of respondents stated they used a multi-file rotary system when performing root canal treatment (RCT), and 18\% reported using both multi-file and single-file systems. the most widely used belonged to the ProTaper multi-file brands, accounting for $78 \%$ of responses. The most used single-file reciprocation brands were WaveOne WO and WaveOne Gold WOG, used by $26 \%$ of respondents. ${ }^{31}$ This study showed that the majority of residents did not use adjunct devices to activate irrigants. However, this maybe be affected by the availability. In one report to evaluate current trends in irrigation among American Association 
of Endodontists members, half of the respondents were using an adjunct, such as ultrasonic activation, to aid in their irrigation technique. ${ }^{6}$ EndoActivator system showed significant effectiveness in removal of collagen from the canal surface, relative to syringe irrigation alone. ${ }^{32}$ The use of sonic activation with EndoActivator did not significantly improve sealer penetration compared with conventional irrigation. ${ }^{33}$ There was a significant percentage of residents who advocated smear layer removal. A web-based Survey emailed to the American Association of Endodontists revealed that endodontists routinely remove the smear layer during endodontic treatment. ${ }^{6}$ One study showed that smear layer presence might decrease the efficiency of sodium hypochlorite irrigant, ${ }^{34}$ while another study showed that smear layer removal improves sealer penetration into dentinal tubules..$^{35}$ In this study, the most common sealers used by residents were zinc oxide-eugenol-based sealers. This selection maybe be affected by the availability and marketing. Zinc oxide-eugenol root canal sealer, showed minimal microleakage compared with calcium hydroxide and resin-based sealers. ${ }^{36}$ Zinc oxideeugenol, and bioceramic and resin-based root canal sealers exhibited antibacterial effects against $\mathrm{E}$. faecalis in the dentinal tubules. Bioceramic and resin-based root canal sealers exhibited superior antibacterial effects compared with zinc oxide-eugenol root canal sealers, ${ }^{37,38}$ as their antibacterial efficacy continued after setting. ${ }^{38}$ Cytotoxicity and genotoxicity of bioceramic-based sealers were less than resin-based sealers AH Plus. ${ }^{39}$ The majority of residents did not advocate sealer extrusion. Extrusion of obturation material may result in an undesired outcome, such as inflammation and severe neurotoxic damage. ${ }^{40}$ Information regarding the effect of apical extrusion of sealer on root canal treatment outcome is scarce. ${ }^{41}$ To evaluate the radiographic healing of a periapical lesion of permanent teeth, after extrusion of an AH Plus sealer, an investigation was conducted, which revealed that extruded AH Plus does not prevent periapical healing, but can contribute to delayed healing in children. ${ }^{42}$ However, a new study revealed that new ceramic-based root canal sealer may be considered minimally cytotoxic, if accidentally extruded into the periapical tissues. ${ }^{43}$

\section{Conclusion}

In conclusion, the current study reveals that residents in the Saudi Board of Endodontics program adopt new technologies in Endodontics, such as the use of an apex locator and NiTi rotary instrumentation; a high percentage of residents also advocate in favor of keeping canal apical patency. Most residents used zinc oxide-eugenol sealers and did not advocate sealer extrusion into the apical foramen. Further, most residents did not use adjunct devices in irrigation, but did advocate smear layer removal. In this study, there exist certain limitations, including the fact that not all residents participated in the survey, limited responses to the questionnaire, inability to verify the accuracy of answers, and the possible biases of respondents. Thus, we are in need of more investigation.

\section{Authors' Contributions}

The authors contributed equally and all authors are in agreement with this manuscript.

\section{Funding}

This research did not receive any specific grant from funding agencies in the public, commercial, or not-for-profit sectors.

\section{Conflict of Interest}

None declared.

\section{Acknowledgments}

We would like to thank the Saudi Board of Endodontics residents who participated in this study. We would also like to thank Editage (www.editage.com) for English language editing.

\section{References}

1 Zou H, Li Y, Lian X, Yan Y, Dai X, Wang G. Frequency and influencing factors of rubber dam usage in tianjin: a questionnaire survey. Int J Dent 2016;2016:7383212. doi: 10.1155/2016/7383212

2 Lababidi EA. Discuss the impact technological advances in equipment and materials have made on the delivery and outcome of endodontic treatment. Aust Endod J 2013;39(3): 92-97

3 Savani GM, Sabbah W, Sedgley CM, Whitten B. Current trends in endodontic treatment by general dental practitioners: report of a United States national survey. J Endod 2014;40(5):618-624

4 Lee M, Winkler J, Hartwell G, Stewart J, Caine R. Current trends in endodontic practice: emergency treatments and technological armamentarium. J Endod 2009;35(1):35-39

5 Clarkson RM, Podlich HM, Savage NW, Moule AJ. A survey of sodium hypochlorite use by general dental practitioners and endodontists in Australia. Aust Dent J 2003;48(1):20-26

6 Dutner J, Mines P, Anderson A. Irrigation trends among American Association of Endodontists members: a web-based survey. J Endod 2012;38(1):37-40

7 Kersten DD, Mines P, Sweet M. Use of the microscope in endodontics: results of a questionnaire. J Endod 2008;34(7):804-807

8 Locke M, Thomas MB, Dummer PM. A survey of adoption of endodontic nickel-titanium rotary instrumentation part 1: general dental practitioners in Wales. Br Dent J 2013;214(3):E6

9 Lynch CD, McConnell RJ. Attitudes and use of rubber dam by Irish general dental practitioners. Int Endod J 2007;40(6):427-432

10 Willershausen I, Wolf TG, Schmidtmann I, et al. Survey of root canal irrigating solutions used in dental practices within Germany. Int Endod J 2015;48(7):654-660

11 Germack M, Sedgley CM, Sabbah W, Whitten B. Antibiotic use in 2016 by members of the American Association of Endodontists: report of a national survey. J Endod 2017;43(10):1615-1622

12 Setzer FC, Hinckley N, Kohli MR, Karabucak B. A Survey of conebeam computed tomographic use among endodontic practitioners in the United States. J Endod 2017;43(5):699-704

13 Ha WN, Duckmanton P, Kahler B, Walsh LJ. A survey of various endodontic procedures related to mineral trioxide aggregate usage by members of the Australian Society of Endodontology. Aust Endod J 2016;42(3):132-138 
14 Alrahabi M. The confidence of undergraduate dental students in Saudi Arabia in performing endodontic treatment. Eur J Dent 2017;11(1):17-21

15 Bird DC, Chambers D, Peters OA. Usage parameters of nickeltitanium rotary instruments: a survey of endodontists in the United States. J Endod 2009;35(9):1193-1197

16 Al-Shamiri HM, Alaizari NA, Al-Maweri SA. Tarakji B. Knowledge and attitude of dental trauma among dental students in Saudi Arabia. Eur J Dent 2015;9(4):518-522

17 Glickman GN, Gluskin AH, Johnson WT, Lin J. The crisis in endodontic education: current perspectives and strategies for change. J Endod 2005;31(4):255-261

18 European Society of Endodontology. Quality guidelines for endodontic treatment: consensus report of the European Society of Endodontology. Int Endod J 2006;39(12):921-930

19 Aggarwal G, Bogra P, Gupta S, Jindal A, Jain N. Determination of apical constriction and apical foramen using electronic apex locator in vivo: Comparison between vital and nonvital teeth. Saudi Endod J 2018;8:99-105

20 American Association of Endodontists, Glossary of Endodontic Terms. 9th ed. Chicago: American Association of Endodontists; 2015

21 Cailleteau JG, Mullaney TP. Prevalence of teaching apical patency and various instrumentation and obturation techniques in United States dental schools. J Endod 1997;23(6):394-396

22 Izu KH, Thomas SJ, Zhang P, Izu AE, Michalek S. Effectiveness of sodium hypochlorite in preventing inoculation of periapical tissues with contaminated patency files. J Endod 2004;30(2):92-94

23 Vera J, Arias A, Romero M. Dynamic movement of intracanal gas bubbles during cleaning and shaping procedures: the effect of maintaining apical patency on their presence in the middle and cervical thirds of human root canals-an in vivo study. J Endod 2012;38(2):200-203

24 Arora M, Sangwan P, Tewari S, Duhan J. Effect of maintaining apical patency on endodontic pain in posterior teeth with pulp necrosis and apical periodontitis: a randomized controlled trial. Int Endod J 2016;49(4):317-324

25 Ustun Y, Aslan T, Sagsen B, Kesim B. The effects of different nickel-titanium instruments on dentinal microcrack formations during root canal preparation. Eur J Dent 2015;9(1):41-46

26 AlRahabi M. Attitudes of general practice dentists in private dental clinics in Almadinah Almunawarah toward novel endodontic technologies. G Ital Endod 2016;30:10-13

27 Alrahabi M, Alkady A. Comparison of the shaping ability of various nickel-titanium file systems in simulated curved canals. Saudi Endod J 2017;7:97-101

28 Özyürek T. Cyclic fatigue resistance of Reciproc, WaveOne, and WaveOne Gold nickel-titanium instruments. J Endod 2016;42(10):1536-1539

29 Berutti E, Chiandussi G, Paolino DS, et al. Canal shaping with WaveOne Primary reciprocating files and ProTaper system: a comparative study. J Endod 2012;38(4):505-509
30 Plotino G, Grande NM, Cotti E, Testarelli L, Gambarini G. Blue treatment enhances cyclic fatigue resistance of vortex nickel-titanium rotary files. J Endod 2014;40(9):1451-1453

31 Blacher JD, Safavi KE, Aseltine RH, Kaufman BM. Defining endodontic residents' clinical experiences: a national survey. JDE 2019;83(5):504-509

32 Bryce G, MacBeth N, Gulabivala K, Ng YL. The efficacy of supplementary sonic irrigation using the EndoActivator system determined by removal of a collagen film from an ex vivo model. Int Endod J 2018;51(4):489-497

33 Bolles JA, He J, Svoboda KK, Schneiderman E, Glickman GN. Comparison of vibringe, endoactivator, and needle irrigation on sealer penetration in extracted human teeth. J Endod 2013;39(5):708-711

34 Morago A, Ordinola-Zapata R, Ferrer-Luque CM, Baca P, Ruiz-Linares M, Arias-Moliz MT. Influence of smear layer on the antimicrobial activity of a sodium hypochlorite/ etidronic acid irrigating solution in infected dentin. J Endod 2016;42(11):1647-1650

35 Kuçi A, Alaçam T, Yavaş O, Ergul-Ulger Z, Kayaoglu G. Sealer penetration into dentinal tubules in the presence or absence of smear layer: a confocal laser scanning microscopic study. J Endod 2014;40(10):1627-1631

36 Shetty V, Hegde P, Chauhan RS, Chaurasia VR, Sharma AM, Taranath M. A spectro photometric comparative evaluation of apical sealing ability of three different sealers; calcium hydroxide based, resin based and zinc oxide eugenol based sealers. J Int Oral Health 2015;7(2):25-27

37 Singh G, Gupta I, Elshamy FM, Boreak N, Homeida HE. In vitro comparison of antibacterial properties of bioceramic-based sealer, resin-based sealer and zinc oxide eugenol based sealer and two mineral trioxide aggregates. Eur J Dent 2016;10(3):366-369

38 Wang Z, Shen Y, Haapasalo M. Dentin extends the antibacterial effect of endodontic sealers against Enterococcus faecalis biofilms. J Endod 2014;40(4):505-508

39 Candeiro GTM, Moura-Netto C, D'Almeida-Couto RS, et al. Cytotoxicity, genotoxicity and antibacterial effectiveness of a bioceramic endodontic sealer. Int Endod J 2016;49(9):858-864

40 Tuğ Kılkış B, Er K, Taşdemir T, et al. Neurotoxicity of various root canal sealers on rat sciatic nerve: an electrophysiologic and histopathologic study. Clin Oral Investig 2015;19(8):2091-2100

41 Ricucci D, Rôças IN, Alves FR, Loghin S, Siqueira JF Jr. Apically extruded sealers: fate and influence on treatment outcome. J Endod 2016;42(2):243-249

42 Sari S, Durutürk L. Radiographic evaluation of periapical healing of permanent teeth with periapical lesions after extrusion of AH Plus sealer. Oral Surg Oral Med Oral Pathol Oral Radiol Endod 2007;104(3):e54-e59

43 Chakar S, Changotade S, Osta N, Khalil I. Cytotoxic evaluation of a new ceramic-based root canal sealer on human fibroblasts. Eur J Dent 2017;11(2):141-148 